\title{
Stability Indicating Rp-HPLC Method for Simultaneous Estimation of Ceftazidime Pentahydrate and its Impurity Product Pyridine in Powder Used for Making Solution in Vial for IM \& IV Injections
}

\author{
MEM Hassouna ${ }^{1 *}$ and MA Mohamed ${ }^{2}$ \\ ${ }^{1}$ Chemistry Department, Beni-Suef University, Egypt \\ ${ }^{2}$ HIKMA group, Pharmaceutical Company, Egypt
}

Submission: November 19, 2017; Published: February 07, 2018

"Corresponding author: MEM Hassouna, Chemistry Department, Faculty of Science, Beni-Suef University, 62514, Egypt, Tel: +2 01223861504

Email: mhassouna47@hotmail.com, Mohamed.hassona@science.bsu.edu.eg

\section{Abstract}

A new, sensitive, precise, simple, and stability indicating RP-HPLC method is developed and validated for simultaneous estimation of Ceftazidime pentahydrate(CFZ) and its impurity product Pyridine(PY) in powder which is used for making solution in vial for intramuscular (IM) \& intravenous (IV) injections. The RP-HPLC method is performed on the Atlantis dc18 column ( $150 \mathrm{~mm} \mathrm{X} 4.6 \mathrm{~mm}, 5 \mu \mathrm{m}$ particle size, using buffer solution of $\mathrm{pH} 7.0$ containing $0.02 \mathrm{M}$ anhydrous sodium acetate: acetonitrile $(60: 40 \mathrm{v} / \mathrm{v})$ as the mobile phase at a flow rate of $1.5 \mathrm{~mL} / \mathrm{min}$, injection volume $20 \mu \mathrm{L}$ and $\mathrm{UV}$ detection at $254 \mathrm{~nm}$. The total run time is 5.0 min.Linear relationships are obtained in the ranges of $100-400 \mu \mathrm{g} /$ $\mathrm{mL}$ and $5-50 \mu \mathrm{g} / \mathrm{mL}$ for CFZ and PY, respectively, with significantly different $\mathrm{R}_{\mathrm{t}}$ values of $1.456 \mathrm{and} 2.970 \mathrm{~min}$ for the two studied drugs. Correlation coefficients (r) $>0.9999$, limits of detection 3.40 and $0.16 \mu \mathrm{g} \mathrm{mL}^{-1}$ and limits of quantitation of 10.33 and $0.49 \mu \mathrm{gL}^{-1}$ have been obtained for $\mathrm{CFZ}$ and PY, respectively. The suggested method is validated according to ICH guidelines. Hence it is suitable for laboratory control of starting materials, bulk and finished products.

Keywords: Ceftazidime Pentahydrate; Pyridine; Validation; Powder for Solution in Vial for IM \& IV Injections; ICH; USP; RP-HPLC

\section{Introduction}

Ceftazidime (CFZ) is a semisynthetic, broad-spectrum, beta-lactam antibiotic for parenteral administration. It is the pentahydrate of pyridinium, 1-[[7-[[(2-amino-4-thiazolyl) [(1-carboxy-1-methylethoxy) imino] acetyl] amino]-2-carboxy8-oxo-5-thia-1-azabicyclo [4.2.0] oct-2-en-3-yl] methyl]-,

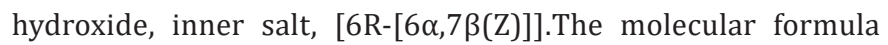
is $\mathrm{C}_{22} \mathrm{H}_{32} \mathrm{~N}_{6} \mathrm{O}_{12} \mathrm{~S}_{2}$, representing a molecular weight of 636.6. [1]. (Figure 1a).<smiles>CC(C)(O/N=C(\C(=O)N[C@H]1C(=O)N2C(C(=O)[O-])=C(C[n+]3ccccc3)CS[C@H]12)c1csc(N)n1)C(=O)O</smiles>

Figure 1a: Chemical structures of (a) Ceftazidime pentahydrate
Ceftazidime for injection, USP is a sterile, dry-powdered mixture of CFZ and sodium carbonate. Sodium carbonate at a concentration of $118 \mathrm{mg} / \mathrm{g}$ of ceftazidime activity has been admixed to facilitate dissolution. The total sodium content of the mixture is approximately $54 \mathrm{mg} / \mathrm{g}$ of CFZ activity [1].

Ceftazidime for injection, USP in sterile crystalline form is supplied in vials equivalent to $1 \mathrm{~g}$ or $2 \mathrm{~g}$ of anhydrous CFZ. CFZ for injection, USP is a white to cream-colored crystalline powder. Solutions of CFZ for injection, USP range in color from light yellow to amber, depending on the diluent and volume used. The $\mathrm{pH}$ of freshly constituted solutions usually ranges from 5 to 8 $[1,2]$.

Ceftazidime is a Cephalosporin bactericidal in action, exerting its effect by inhibition of enzyme 84 responsible for cell-wall synthesis. A wide range of gram-negative organisms is susceptible to $85 \mathrm{CFZ}$ in vitro, including strains resistant to gentamicin and other amino glycosides. In 86 additions, CFZ has been shown to be active against gram-positive organisms. It is highly 87 stable to most clinically important beta-lactamases, 
plasmid or chromosomal, which are produced 88 by both gramnegative and gram-positive organisms and, consequently, is active against many 89 strains resistant to ampicillin and other cephalosporins [1].

Ceftazidime pentahydrate with sodium carbonate for injection is a sterile mixture of CFZ (1405) and anhydrous sodium carbonate (0773). CFZ is a semi-synthetic product derived from a fermentation product and freely soluble in water and in methanol, practically insoluble in acetone $[3,4]$.

Pyridine (PY); is chemically known as azabenzene. It has a molecular formula of $\mathrm{C}_{5} \mathrm{H}_{5} \mathrm{~N}$ and a molecular weight of $79.102 \mathrm{~g} /$ mol [5](Figure 1b).

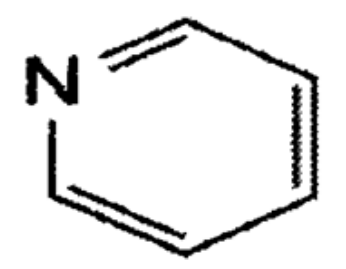

(b)

Figure 1b: Chemical structures of (b) Pyridine.

Pyridine is a clear colorless to light yellow liquid with an unpleasant smell an odor that is sour, putrid, fish-like., penetrating and nauseating. Its density is $0.978 \mathrm{~g} / \mathrm{cm}^{3}$ and flash point at $68^{\circ} \mathrm{F}$. Vapors are heavier than air, toxic by ingestion and inhalation. On combustion, it produces toxic oxides of nitrogen. It is a relatively simple heterocyclic aromatic organic compound that is structurally related to benzene, with one $\mathrm{CH}$ group in the six-membered ring replaced by a nitrogen atom. It is obtained from crude coal tar or is synthesized from acetaldehyde, formaldehyde and ammonia. It can also be formed from the breakdown of many natural materials in the environment [5]. PY is often used as a denaturant for antifreeze mixtures, for ethyl alcohol, for fungicides, and as a dyeing aid for textiles. It is also used to make many different products such as medicines, vitamins, food flavorings, paints, dyes, rubber products, adhesives, insecticides, and herbicides. It is a harmful substance if inhaled, ingested or absorbed through the skin. In particular, it is known to reduce male fertility and is considered carcinogenic. Common symptoms of acute exposure to PY include: headache, coughing, asthmatic breathing, laryngitis, nausea and vomiting [5].

Ceftazidimeis official in British Pharmacopeia (BP), European Pharmacopeia (EP) $[3,4]$ and United States Pharmacopeia (USP) [2], they all include HPLC method for estimation of CFZ.

Literature review showed that various analytical methods have been described for the estimation of CFZ including spectrophotometric [6-14], capillary electrophoresis [15-18], thin layer chromatography (TLC) [19-21], high performance liquid chromatography (HPLC) [22-31],electrochemical and voltammetric methods [32,33] have been reported for the estimation of CFZ in pure or in dosage forms. Pyridine is official in BP, EP [3,4] and United States Pharmacopeia (USP) [2] and is determined by high-performance liquid chromatography (HPLC) [34].

According to the best of our knowledge, only one RP-HPLC method was reported for the simultaneous estimation of both CFZ and PY together in Eye Drop Formulation [35], but there is no RP-HPLC one reported for the simultaneous estimation of both CFZ and its impurity product PY in powder that is applied for making solution used in vial for IM \& IV injections.

Thus, the present study aims to develop a simple, sensitive, short retention time and accurate RP-HPLC method for the simultaneous estimation of both CFZ and its impurity product PY in powder used for solution in Vial for IM \& IV injections with high sensitivity, accuracy that are required to be applied in routine laboratory control analysis and validate the developed method according to ICH guidelines [36].

\section{Materials and Methods}

\section{Apparatus}

a. HPLC system (Shimadzu LC SPD $20 \mathrm{~A}$ ) with a detector (dual wavelength), equipped with a binary pump, Auto sampler, oven CTO-20A/20AC with temperature range (10$85^{\circ} \mathrm{C}$ ), LC Solution software.

b. pH mettler Toledo

c. Advanced Performance Uni Bloc Balances AP Series (Shimadzu) Ultra-sonic bath Elmasonic S

\section{Pure Samples}

Pure samples of CFZ and PY were kindly supplied by EPCI Pharmaceutical Company part of HIKMA group, Beni-Suef, Egypt with claimed purity of $98.10 \%$ and $99.90 \%$, respectively, according to certificates of analysis.

\section{Pharmaceutical Dosage Form}

KEFADIM $R_{t} 1.0$ gm (Batch No. F1540062); each vial is claimed to contain $1165 \mathrm{mg}$ of $\mathrm{CFZ}$ pentahydrate (equivalent to $1000 \mathrm{mg}$ of $\mathrm{CFZ}$ base)and $118 \mathrm{mg}$ of sodium carbonate and KEFADIM $R_{t} 500 \mathrm{mg}$ (Batch No. F1540199); each vial is claimed to contain $580 \mathrm{mg}$ of CFZ pentahydrate (equivalent to $500 \mathrm{mg}$ of CFZ base)and $59 \mathrm{mg}$ of sodium carbonate are manufactured by EPCI Pharmaceutical Company part of HIKMA group, Beni-Suef, Egypt.

\section{Storage conditions}

a. Prior to reconstitution: Protect from light. Store at 15$30^{\circ} \mathrm{C}$.

b. After reconstitution: Store in a refrigerator and use within 7 days. If kept at room temperature, use within 24 hours. 
c. Once reconstituted, light protection is not needed.

\section{Chemicals}

Acetonitrile HPLC grade, distilled water and anhydrous sodium acetate analytical grade are procured from (scharlau, Spain).

\section{Mobile phase preparation: Acetate Buffer pH (7.0): Acetonitrile (60:40)}

Sodium acetate buffer is prepared by dissolving $1.64 \mathrm{gm}$ of anhydrous sodium acetate in $700 \mathrm{ml}$ distilled water, sonicate to dissolve and adjust $\mathrm{pH}$ to 7.0 by ortho phosphoric acid solution. Make up to $1000 \mathrm{~mL}$ with distilled water, filter and degass mixtures of buffer and acetonitrile $(60: 40)$ through $0.45 \mu$ membrane filter under vacuum pump.

\section{Diluent}

Sodium acetate buffer $\mathrm{pH}$ (7.0)

\section{HPLC Chromatographic Conditions}

Chromatographic separation is performed on the Atlantis dc18 column (150 mm X $4.6 \mathrm{~mm}, 5 \mu \mathrm{m}$ particle size, using buffer solution of pH 7.0 containing $0.02 \mathrm{M}$ anhydrous sodium acetate: acetonitrile $(60: 40 \mathrm{v} / \mathrm{v})$ as the mobile phase at a flow rate of 1.5 $\mathrm{mL} / \mathrm{min}$, injection volume $20 \mu \mathrm{L}$ and UV detection at $254 \mathrm{~nm}$. The total run time is $5.0 \mathrm{~min}$.

Application to Pharmaceutical Formulation (KEFADIM $\left(R_{t}\right)$ 1.0 Gm\& 500 Mg Vial): Transfer about $395 \mathrm{mg}$ of CFZ for injection (equivalent to $360 \mathrm{mg}$ CFZ base), just removed from its container and accurately weighed, to a $100-\mathrm{mL}$ volumetric flask, promptly add pH 7 buffer to volume, and mix. Transfer an accurately 10

\section{Preparation of Standard and Sample Solutions}

Stock Solutions of Ceftazidime and Pyridine (1000 Mg / Ml): $100 \mathrm{mg}$ of each of CFZ and PY working standards are weighed accurately, transfer to $100 \mathrm{~mL}$ volumetric flask, add $70 \mathrm{~mL}$ of diluent and sonicate to dissolve and complete the volume to the mark with the same diluent and mix well.

Working Standard Solutions of Ceftazidime and Pyridine (350\&15 $\mu \mathrm{g} / \mathrm{Ml}$ ): Take $35 \mathrm{~mL}$ aliquot from the stock solutions of CFZ and $1.5 \mathrm{~mL}$ of PY into $100 \mathrm{~mL}$ volumetric flask, add 70 $\mathrm{mL}$ of diluent and sonicate to dissolve and volume is completed to the mark with the diluent and mixed well. The obtained chromatogram is shown in (Figure 2).

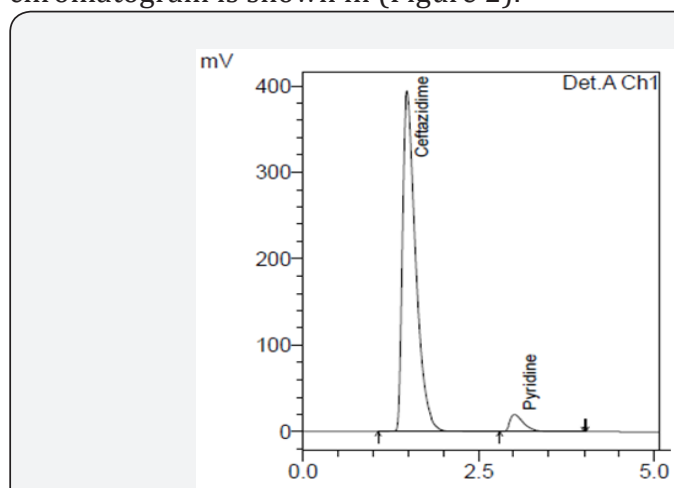

Figure 2: HPLC Chromatogram of an authentic mixture of $(300 \mu \mathrm{g} / \mathrm{mL})$ of CFZ and $(15 \mu \mathrm{g} / \mathrm{mL})$ PY, respectively.

$\mathrm{mL}$ aliquot of the resulting suspension into $100 \mathrm{~mL}$ volumetric flask. Sonicate if necessary to ensure complete dissolution. Filter to obtain the clear assay preparation. Store this solution in a cool place, and use it within 1 hour. The obtained chromatogram is shown in (Figure 3a \& 3b).
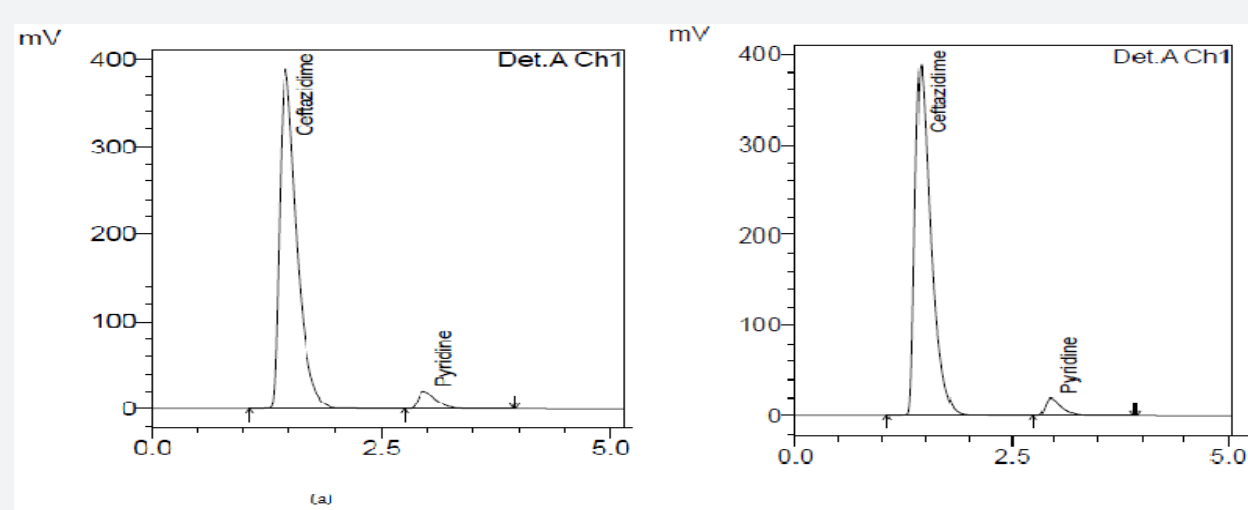

(b)

Figure 3: HPLC Chromatogram of assay for (a) sample of KEFADIM 1.0gm and (b) sample of KEFADIM 500mgvials for injections.

Separately inject equal volumes (about $20 \mu \mathrm{L}$ ) of the standard solution and the test one into the chromatograph, record the chromatograms, and measure the areas of the responses for the pyridine peaks. Calculate the percentage of pyridine in the portion of ceftazidime for injection taken by the formula:

$$
10(\mathrm{C} / \mathrm{W})(\mathrm{rU} / \mathrm{rS}) \text {, }
$$

where $\mathrm{C}$ is the concentration in $\mu \mathrm{g}$ per $\mathrm{mL}$, of pyridine in the standard solution; $\mathrm{W}$ is the weight in $\mathrm{mg}$, of ceftazidime for injection taken; and $\mathrm{rU}$ and $\mathrm{rS}$ are the pyridine peak responses obtained from the test solution and the standard one, 
respectively: not more than $0.4 \%$ of pyridine is found where it contains sodium carbonate; and not more than $0.3 \%$ where it contains arginine. Also, the standard addition technique has been carried out to assess the validity of the method by spiking the pharmaceutical formulation with known amounts of both standard solutions of CFZ and PY. The recovery of the added standards is then calculated after applying the proposed method.

\section{Construction of Calibration Curves}

Different concentrations of CFZ and PY equivalent to (100400) $\mu \mathrm{g} / \mathrm{mL}$ and (5-50) $\mu \mathrm{g} / \mathrm{mL}$ for CFZ and PY, respectively, are separately withdrawn from their respective stock standards into separate series of $100 \mathrm{~mL}$ volumetric flasks, and the volumes are made up to volume with the diluent. Duplicate $20 \mu \mathrm{L}$ injections are made for each concentration maintaining the flow rate at $1.5 \mathrm{~mL} / \mathrm{min}$ and the effluent is UV-scanned at $254 \mathrm{~nm}$. The chromatographic separation is performed following the procedure under chromatographic conditions. The chromatograms are recorded, peak areas of CFZ and PY are determined and the calibration curves relating the obtained integrated peak areas to the corresponding concentrations are constructed and the regression equations are performed.

\section{Results and Discussion}

The aim of this work is to introduce simple, sensitive, accurate, precise and smart RP-HPLC method forsimultaneous estimation of CFZ and its impurity product PY in powder used for making solution in vial for IM \& IV injections. Also, to determine the concentration and recovery for laboratory prepared mixtures and subjecting them to the standard addition technique. Chromatograms are obtained with significantly different $R_{t}$ values of 1.456 and 2.970 min for CFZ and PY with correlation coefficient $(r)>0.9999$, limits of detection 3.40 and $0.16 \mu \mathrm{g} \mathrm{mL}^{-1}$ and limits of quantization of 10.33 and $0.49 \mu \mathrm{g} \mathrm{mL}^{-1}$ for CFZ and PY, respectively. No occurrence of interfering peaks has been detected.

\section{Methods Development and Optimization}

In order to achieve the suggested method; different developing conditions of different compositions, columns, flow rates, wavelengths, diluents and ratios were tried including: methanol: water $(50: 50, \mathrm{v} / \mathrm{v})$, methanol: water $(70: 30$, $\mathrm{v} / \mathrm{v})$, acetonitrile: water $(50: 50, \mathrm{v} / \mathrm{v})$, acetonitrile: water $(70: 30$, $\mathrm{v} / \mathrm{v}$ ) and anhydrous sodium acetate-phosphate buffer $\mathrm{pH}$ (5.0): ACN (50:50, v/v), split peaks are observed. Finally, using a mixture of anhydrous sodium acetate-phosphate buffer $\mathrm{pH}$ (7.0): $\operatorname{ACN}(60: 40, v / v)$, it was found that this mixture is the most appropriate one for the separation of both drugs.

Different flow rates $(0.7,1.0,1.2$ and $1.5 \mathrm{~mL} / \mathrm{min})$, scanning wavelengths (200-400 nm) were also tried for both drugs in pure form, 254nm proved as the best suitable value for detecting both drugs. Preliminary studies involved trying C18, C8 reversedphase columns. The best developing system is anhydrous sodium acetate-phosphate buffer pH (7.0): ACN (60:40, v/v) at flow rate of $1.5 \mathrm{~mL} / \mathrm{min}$ and UV-detection at wavelength of $254.0 \mathrm{~nm}$ using Atlantis dc18 column ( $150 \mathrm{~mm}$ X $4.6 \mathrm{~mm}, 5 \mu \mathrm{m}$ particle size). This selected developing system allows good resolution between both drugs and obtaining sharp peaks with good Rt values without tailing of the separated bands and good theoretical plates.

\section{Validation of the Analytical Method}

The method is validated, in accordance with ICH guidelines (ICH Q2R1), for system suitability, precision, accuracy, linearity, specificity, ruggedness, robustness, LOD and LOQ [36].

Linearity and Range: The linearity of an analytical procedure is its ability (within a given range) to obtain test results which are directly proportional to the concentration (amount) of analyte in the sample. The range of an analytical procedure is the interval between the upper and lower concentration (amounts) of analyte in the sample (including these concentrations) for which it has been demonstrated that the analytical procedure has a suitable level of precision, accuracy and linearity. The linearity of the proposed method is obtained in the concentration range $(100.0-400.0 \mu \mathrm{g} / \mathrm{mL}$ ) for CFZ and (5.0 - $50.0 \mu \mathrm{g} / \mathrm{mL})$ for PY. Calibration curves are composed by plotting peak areas against the corresponding concentration. The obtained coefficients of regression are 0.9999 , for both CFZ and PY. Linearity results are shown in (Table 1).

Table 1: Regression and validation parameters of the proposed HPLC method for determination of CFZ and PY.

\begin{tabular}{|c|c|c|}
\hline Parameter & CFZ & PY \\
\hline Linear & & \\
\hline range $(\mu \mathrm{g} / \mathrm{mL})$ & $10-400$ & May-50 \\
\hline Slope & 17288.8753 & 18192.272 \\
\hline Intercept & 39559.7119 & 2795.0311 \\
\hline Correlation coefficient & 0.9999 & 0.9999 \\
\hline LOD $^{\text {a }}(\mu \mathrm{g} / \mathrm{mL})$ & 3.4 & 0.16 \\
\hline LOQ $^{\text {a }}(\mu \mathrm{g} / \mathrm{mL})$ & 10.33 & 0.49 \\
\hline Repeatability & & 0.23 \\
\hline
\end{tabular}

a Limit of detection $(3.3 \times \sigma /$ Slope $)$ and limit of quantization $(10 \times$ $\sigma /$ Slope).

${ }^{b}$ Repeatability for $n \geq 5$, RSD $\leq 2$.

Repeatability: Repeatability expresses the precision under the same operating conditions over a short interval of time. Repeatability is also termed intra-assay precision. Repeatability of the method is evaluated by calculating the RSD of the peak areas of six replicate injections for the standard concentrations $(300.0 \mu \mathrm{g} / \mathrm{mL})$ of CFZ and $(15.0 \mu \mathrm{g} / \mathrm{mL})$ of PY. Results are expressed as \% RSD values of the concentrations of determined drugs. Low values of \% RSD (less than 2) indicate high precision of the method as shown in (Table 1).

Detection and Quantization Limits: The detection limit of an individual analytical procedure is the lowest amount of analyte in a sample which can be detected but not necessarily quantitated as an exact value. The quantization limit of an 
individual analytical procedure is the lowest amount of analyte in a sample which can be quantitatively determined with suitable precision and accuracy. The quantization limit is a parameter of quantitative assays for low levels of compounds in sample matrices, and is used particularly for the determination of impurities and/or degradation products. These approaches are based on the Standard Deviation of the Response and the Slope. A specific calibration curve should be studied using samples containing an analyte in the range of LOD and LOQ. The residual standard deviation of a regression line or the standard deviation of $y$-intercepts of regression lines may be used as the standard deviation. $\mathrm{LOD}=3.3 \times \sigma /$ slope and $\mathrm{LOQ}=10 \times \sigma /$ slope, where $\sigma=$ the standard deviation of the response (Table 1 ).
Accuracy and Recovery: Accuracy of the suggested method is calculated as the percentage recoveries of pure samples of the studied drugs. Accuracy is assessed using three different concentrations $(100,200 \& 300 \mu \mathrm{g} / \mathrm{mL})$ for CFZ and (10, $20 \& 30 \mu \mathrm{g} / \mathrm{mL}$ ) for PY within the linearity range (i.e. three concentrations and three replicates). Concentrations are calculated from the corresponding regression equations. The mean \% recoveries for CFZ and PY are between $98.0 \%$ and $102 \%$. These data are shown in Table 2. Accuracy is further assessed by applying the standard addition technique to KEFADIM $® 1.0 \mathrm{gm}$. where good recoveries are obtained revealing that there is no interference from excipients (Table 3).

Table 2: Data of Accuracy for CFZ and PY.

\begin{tabular}{|c|c|c|c|c|c|c|c|}
\hline $\begin{array}{l}\text { Ceftazidime } \\
\text { Standard }\end{array}$ & \multicolumn{3}{|c|}{ CFZ } & \multirow{2}{*}{$\begin{array}{l}\text { Pyridine } \\
\text { Standard } \\
(\mu \mathrm{g} / \mathrm{mL})\end{array}$} & \multicolumn{3}{|c|}{ PY } \\
\hline & $\begin{array}{c}\mu \mathrm{g} / \mathrm{mL} \\
\text { (Injected) }\end{array}$ & $\mu \mathrm{g} / \mathrm{mL}$ (found) & $\begin{array}{c}\text { Recovery } \\
\%\end{array}$ & & $\underset{\text { (Injected) }}{\mu \mathrm{g} / \mathrm{mL}}$ & $\mu \mathrm{g} / \mathrm{mL}$ (found) & Recovery \% \\
\hline \multirow{3}{*}{100} & 100 & 101.1 & 101.1 & \multirow{3}{*}{10} & 10 & 9.81 & 98.08 \\
\hline & 100 & 101.06 & 101.06 & & 10 & 9.8 & 98.02 \\
\hline & 100 & 101 & 101 & & 10 & 9.81 & 98.14 \\
\hline \multirow{3}{*}{200} & 200 & 200.28 & 100.14 & \multirow{3}{*}{20} & 20 & 20.11 & 100.55 \\
\hline & 200 & 200.75 & 100.37 & & 20 & 19.97 & 99.86 \\
\hline & 200 & 200.6 & 100.3 & & 20 & 20.01 & 100.06 \\
\hline \multirow{3}{*}{300} & 300 & 297.2 & 99.07 & \multirow{3}{*}{30} & 30 & 30.46 & 101.54 \\
\hline & 300 & 297.23 & 99.08 & & 30 & 30.48 & 101.59 \\
\hline & 300 & 294.78 & 98.26 & & 30 & 30.46 & 101.52 \\
\hline $\begin{array}{c}\text { Accuracy } \\
\text { (Mean) }\end{array}$ & \multicolumn{3}{|c|}{100.04} & $\begin{array}{c}\text { Accuracy } \\
\text { (Mean) }\end{array}$ & \multicolumn{3}{|c|}{99.93} \\
\hline
\end{tabular}

Table 3: Determination of CFZ and PY in pharmaceutical formulation by the proposed HPLC method and application of standard addition technique.

\begin{tabular}{|c|c|c|c|c|}
\hline \multirow{2}{*}{$\begin{array}{c}\text { Pharmaceutical } \\
\text { Formulation }\end{array}$} & \multicolumn{2}{|c|}{ Added $(\mu \mathrm{g} / \mathrm{mL})$} & \multicolumn{2}{c|}{ Recovery \% } \\
\cline { 2 - 5 } & CFZ & PY & 100.38 & 100.46 \\
\hline KEFADIM 1.0 GM & 20 & 10 & 100.63 & 101.02 \\
\hline CFZ, 1000 mg(claimed) & 30 & 15 & 100.73 & 100.38 \\
\hline PY,50 mg(claimed) & 40 & & $100.58 \pm 0.18$ & $100.29 \pm 0.23$ \\
\hline Mean \pm RSD & & 5 & & PF \\
\hline
\end{tabular}

Formulation Assay: The validated method is applied to the determination of CFZ and PYin commercially available KEFADIM Rt 1. 0gm and KEFADIM Rt 500mg. The results of the assay undertaken yielded $100.24 \%, 100.63 \%$ and $0.37 \%, 0.38 \%$ of the label claim for CFZ and PY, respectively. The results of the assay indicate that the method is selective for the analysis of KEFADIM Rt 1.0 gm and KEFADIM Rt 500mg vials for I.M or I.V injections without interference from the excipients used to formulate and produce these suspensions. The results are displayed in Tables 4,5 . 


\section{Annals of Reviews and Research}

Table 4: Assay results for the determination of CFZ and PY in pharmaceutical formulation by the proposed HPLC method.

\begin{tabular}{|c|c|c|c|c|c|c|}
\hline \multirow{2}{*}{$\begin{array}{l}\text { Pharmaceutical } \\
\text { Formulation }\end{array}$} & \multicolumn{2}{|c|}{ Conc. $(\mu \mathrm{g} / \mathrm{Ml})$} & \multicolumn{2}{|c|}{ Recovery \% } & \multicolumn{2}{|c|}{ Limit \% } \\
\hline & CFZ & PY & CFZ & PY & CFZ & PY \\
\hline \multirow{7}{*}{$\begin{array}{l}\text { KEFADIM } 1.0 \text { GM } \\
\text { CFZ, } 1000 \text { mg(claimed) } \\
\text { PY,50 mg(claimed) } \\
\text { Mean } \pm \text { RSD }\end{array}$} & 1000 & 50 & 100.48 & 0.37 & \multirow{7}{*}{$(90-110)$} & \multirow{7}{*}{ NMT $0.4 \%$} \\
\hline & & & 100.48 & 0.37 & & \\
\hline & & & 100.35 & 0.37 & & \\
\hline & & & 100.18 & 0.37 & & \\
\hline & & & 100.78 & 0.37 & & \\
\hline & & & 99.16 & 0.37 & & \\
\hline & & & $100.24 \pm 0.56$ & $0.37 \pm 0.97$ & & \\
\hline
\end{tabular}

Table 5: Assay results for the determination of CFZ and PY in pharmaceutical formulation by the proposed HPLC method

\begin{tabular}{|c|c|c|c|c|c|c|}
\hline \multirow{2}{*}{$\begin{array}{l}\text { Pharmaceutical } \\
\text { Formulation }\end{array}$} & \multicolumn{2}{|c|}{ Conc. $(\mu \mathrm{g} / \mathrm{Ml})$} & \multicolumn{2}{|c|}{ Recovery \% } & \multicolumn{2}{|c|}{ Limit \% } \\
\hline & CFZ & PY & CFZ & PY & CFZ & PY \\
\hline \multirow{7}{*}{$\begin{array}{l}\text { KEFADIM } 500 \text { MG } \\
\text { CFZ, } 500 \text { mg(claimed) } \\
\text { PY,25 mg(claimed) } \\
\text { Mean } \pm \text { RSD }\end{array}$} & 100 & 2.5 & 100.95 & 0.37 & \multirow{7}{*}{$(90-110)$} & \multirow{7}{*}{ NMT $0.4 \%$} \\
\hline & & & 100.33 & 0.37 & & \\
\hline & & & 100.22 & 0.37 & & \\
\hline & & & 100.74 & 0.38 & & \\
\hline & & & 100.55 & 0.38 & & \\
\hline & & & 101.04 & 0.38 & & \\
\hline & & & $100.63 \pm 0.32$ & $0.38 \pm 0.44$ & & \\
\hline
\end{tabular}

Intermediate Precision (Ruggedness): Intermediate precision expresses within-laboratories variations: different days, different analysts, different equipment's, etc. Good results are obtained and presented in Table 6.

Table 6: Ruggedness of the method.

\begin{tabular}{|c|c|c|}
\hline Parameter (\% RSD) & CFZ & PY \\
\hline Intraday & 0.18 & 0.15 \\
\hline Interday & 0.99 & 0.58 \\
\hline Analyst to Analyst & 0.16 & 0.45 \\
\hline Column to Column & 0.97 & 0.78 \\
\hline
\end{tabular}

Robustness: The robustness of the proposed method is evaluated in the development phase where the effects of different factors on the method are studied to obtain the optimum parameters for complete separation. Robustness of the method is studied by deliberately varying parameters like flow rate $( \pm 0.1 \mathrm{~mL} / \mathrm{min})$

Table 7: Robustness of the method.

\begin{tabular}{|c|c|c|}
\hline Parameter(\%RSD) & CFZ & PY \\
\hline \multirow{2}{*}{$\begin{array}{l}\text { Flow Rate Change } \\
( \pm 0.1 \mathrm{~mL} / \mathrm{min})\end{array}$} & & \\
\hline & 1.11 & 0.88 \\
\hline \multirow{2}{*}{$\begin{array}{l}\mathrm{pH} \text { Changes of Mobile Phase } \\
\qquad \pm 0.2)\end{array}$} & & \\
\hline & 0.98 & 0.8 \\
\hline \multirow{2}{*}{$\begin{array}{l}\text { Wave Length Change } \\
\qquad(254 \mathrm{~nm} \pm 1)\end{array}$} & & \\
\hline & 0.67 & 0.88 \\
\hline \multirow{2}{*}{$\begin{array}{l}\text { Column Temperature Change } \\
\qquad\left(25 \pm 5^{\circ} \mathrm{C}\right)\end{array}$} & & \\
\hline & 0.89 & 0.77 \\
\hline
\end{tabular}

and studying the effect of changing mobile phase $\mathrm{pH}$ by $( \pm 0.2)$, acetonitrile composition $( \pm 5 \%)$ and column temperature change $\left(25\left( \pm 5^{\circ} \mathrm{c}\right)\right.$. The low values of the $\%$ RSD, as given in Table 7 , indicate the robustness of the method. 
System Suitability: System suitability testing is an integral part of many analytical procedures. The tests are based on the concept that the equipment, electronics, analytical operations and samples to be analyzed constitute an integral system that can be evaluated as such. System suitability is checked by calculating tailing factor $(\mathrm{T})$, column efficiency $(\mathrm{N})$, resolution (Rs) factors. All calculated parameters are within the acceptable limits indicating good selectivity of the method and ensuring system performance (Table 8).

Table 8: System suitability testing parameters of the developed method.

\begin{tabular}{|c|c|c|c|}
\hline \multirow{2}{*}{ Item } & \multicolumn{2}{|c|}{ Obtained Value } & \multirow{2}{*}{ Reference Values } \\
\cline { 2 - 4 } & CFZ & PY & T $\leq 2$ \\
\hline Tailing Factor & 1.866 & 1.901 & $\mathrm{Rs}>2$ \\
\hline Resolution & - & 4.323 & $\mathrm{k}>2$ \\
\hline Selectivity & - & 4 & $\mathrm{RSD} \leq 1 \%$ \\
\hline Injection Precision & 0.18 & 0.23 & $\mathrm{RSD} \leq 1 \%$ \\
\hline Retention Time $\left(\mathrm{R}_{\mathrm{t}}\right)$ & 0.09 & 0.12 & $\mathrm{~N}>2000$ \\
\hline Number of Theoretical Plates(N) & 6500.632 & 6840.221 & \\
\hline
\end{tabular}

Stability of Analytical Solution: To demonstrate the stability of standard solution during analysis, solution is analyzed over a period of $24 \mathrm{~h}$ at room temperature and in refrigerator. The results showed that for all the solutions, the retention times and peak areas of CFZ and PY remained almost unchanged $(\mathrm{RSD}<2.0 \%)$ indicating that no significant degradation occurred within this period. Thus, both solutions are stable for at least 24 $\mathrm{h}$, which is sufficient to complete the whole analytical process.

The results are displayed in Table 9.

Table 9: Results of stability of analytical solution.

\begin{tabular}{|c|c|c|}
\hline Condition & CFZ & PY \\
\hline Fridge $\left(2-8^{\circ} \mathrm{C}\right)$ & $100.21 \%$ & $101.14 \%$ \\
\hline Room temperature $\left(25^{\circ} \mathrm{C}\right)$ & $98.09 \%$ & $100.75 \%$ \\
\hline
\end{tabular}

Specificity: Specificity is tested against standard compounds and against potential interferences in the presence of placebo. No interferences are detected at the retention times of both studied drugs in placebo solution.

\section{Conclusion}

The proposed RP-HPLC method for simultaneous estimation of Ceftazidime pentahydrate and its impurity product Pyridine in powder used for making solution in vial for IM \& IV injections is novel, precise, specific, accurate, less time consuming, low cost and rapid. Based on the results of stress testing undertaken according to the International Conference on Harmonization (ICH) guidelines, stability of tested drugs is evaluated. The method can be used for regular routine analysis and stability study. However, further studies are needed in order to determine the sodium carbonate content in combination with both drugs in powder used for making solution in vial for IM \& IV injections.

\section{Acknowledgment}

The authors are thankful to HIKMA group, Pharmaceutical Company, Beni-Suef, Egypt for supporting this work.

\section{Compliance with Ethical Standards}

\section{Conflict of Interest}

The authors declare no conflict of interest

\section{Ethical Approval}

This article does not contain any studies with human participants or animals performed by any of the authors.

\section{References}

1. Ceftazidime

2. The United States Pharmacopoeia, $40^{\text {th }}$ Revision, NF 35, The United States Pharmacopoeia Convention Inc., June 1, 2017.

3. British Pharmacopoeia, Stationary Office, Medicines and Healthcare Products Regulatory Agency, London, Vol. II, 2017.

4. (2014) iv. Contents of the $8^{\text {th }}$ edition. European Pharmacopeia.

5. National Center for Biotechnology Information. Pub Chem Compound Database; CID=1049.

6. Moreno AH, Salgado HRN (2008) Spectrophotometric determination of ceftazidime in pharmaceutical preparations using neocuproin as a complexing agent. Analytical Letters 41(12): 2143-2152.

7. Moreno AH, Salgado HRN (2009) Rapid and selective UV spectrophotometric method for the analysis of ceftazidime. J AOAC Int 92(3): 820-823.

8. Arun K, Saravanan C, Balachandar R, MV Kumuthavalli, B Jayakar (2010) UV-Spectrophotometric determination of ceftazidime in pure and pharmaceutical formulation. J Chem Pharm Res 2(1): 424-431.

9. Hiremath B, Mruthyunjayaswamy BH (2008) Development and validation of spectrophotometric methods for determination of ceftazidime in pharmaceutical dosage forms. Acta Pharm 58(3): 275285. 
10. L Mohan Krishna, P Jayachandra Reddy, V Jaya Sankar Reddy, KVS Prasada Rao (2011) Assay of Ceftazidime In Bulk And its pharmaceutical formulations by visible spectro photometry. Rasayan J Chem 4(3): 561-566'\{\{Siddiqui, 2009 \#1\}

11. Kalyani L, Rao CV (2017) Simultaneous estimation of Sulbactam and Ceftazidime in combined pharmaceutical dosage form by Visible, Ultraviolet and First order derivative Spectrophotometric methods.International Journal of Chemical and Pharmaceutical Sciences 8(1): 28-35.

12. Patel SA, Patel H, Patel NJ (2011) Validated spectrophotometric for estimation of ceftazidime in dry powder for injection. IRJP 2(11): 166168.

13. Dung NT, Dao DT, Hoat GD, Son NA (2017) Development of Spectrophotometric Method for Determination of Ceftazidime with The Bratton Marshall Reagent In Pharmaceutical Preparation. Journal of Science and Technology 55(2): 220-228.

14. Nanda RK, Shelke AV, Panchaware MS (2012) UV Spectrophotometric for Simultaneous Estimation of Ceftazidime Sodium and Tazobactum sodium in Dry Powder Injection. Asian journal of research in Chemistry 5(5): 586-590.

15. Xu W, Gao P, Zhang X, Song L (2008) Evaluation of Ceftazidime contents in antibiotic discs by capillary electrophoresis. New Microbiol 31(3): 377-381.

16. Wang R, Chen LR, Jia ZP, Xie JW, Hu XL, et al. (2002) Simultaneous enantiomeric separation of ceftazidime and cefriaxone sodium by capillary electrophoresis. Chinese Journal of Analytical Chemistry 30(9): 1070-1073?

17. Gáspár A, Kardos S, Andrasi M, Klekner A (2002) Capillary electrophoresis for the direct determination of cephalosporins in clinical samples. Chromatographia 56(1): 109-114.]

18. Bolshakov DS, Amelin VG, Nikeshina TB (2016) Determination of antibiotics in drugs and biological fluids using capillary electrophoresis. Journal of analytical chemistry 71(3): 215-233.

19. Nabi SA, Laiq E, Islam A (2004) Selective separation and determination of cephalosporins by TLC on stannic oxide layers. Acta Chromatographica 14: 92-101.

20. Nanda RK, Shelke AV (2012) Development and validation of HPTLC method for the simultaneous estimation of ceftazidime sodium and tazobactam sodium in marketed formulation. International Journal of Chem Tech Research 4(4): 1701-1707.

21. Khandagle KS, Gandhi SV, Deshpande PB, Kale AN, Deshmukh PR (2010) High Performance Thin Layer Chromatographic determination of Cefixime and Ofloxacin in combined tablet dosage form. J Chem Pharm Res 2(5): 92-96.

22. Ehrlich M, Daschner FD, Kümmerer K (2001) Rapid antibiotic drug monitoring: Meropenem and ceftazidime determination in serum and bronchial secretions by high-performance liquid chromatographyintegrated sample preparation. J Chromatogr B Biomed Sci App 751(2): 357-363.

23. Moreno AH, Salgado HRN (2008) Development of a new highperformance liquid chromatographic method for the determination of ceftazidime. J AOAC Int 91(4): 739-743.'
24. Hanes SD, Herring VL, Wood GC (1998) Alternative method for determination of ceftazidime in plasma by high-performance liquid chromatography. J Chromatogr B Biomed Sci Appl 719(1): 245-250.

25. Chan CY, Chan K, French GL (1986) Rapid high-performance liquid chromatographic assay of cephalosporins in biological fluids. J Antimicrob Chemother 18(4): 537-545'.

26. Ye G, Cai X, Wang B, Zhou Z, Yu X, et al. (2008) Simultaneous determination of vancomycin and ceftazidime in cerebrospinal fluid in craniotomy patients by high-performance liquid chromatography. J Pharm Biomed Anal 48(3): 860-865.

27. Jiang E, Hu C (2008) Determination of ceftazidime and impurities using high performance liquid chromatography. Se Pu 26(1): 75-79.

28. Siddiqui MR, Tariq A, Chaudhary M, Reddy KD, Negi PS, et al. (2009) Development and validation of high performance liquid chromatographic method for the simultaneous determination of ceftazidime and sulbactam in spiked plasma and combined dosage form-zydotam. American Journal of Applied Sciences 6(10): 17811787.

29. Moreno AH, Salgado HRN (2012) Comparison of high performance liquid chromatography and three titrimetric methods for the determination of ceftazidime in pharmaceutical formulations. Advances in Analytical Chemistry 2(3): 6-13.

30. Meng XM, Meng ZY,ZhangL, Dou GF (2004) Simultaneous determination of ceftazidime and tazobactam in injectable powder by reversed-phase high performance liquid chromatography 13(4): 267-270.]

31. Suryawanshi G, Bandal R, Harole Mangesh H, Kalyan P (2016) A validated stability indicating RP-HPLC method for simultaneous determination of avibactam and ceftazidime in bulk and pharmaceutical dosage from. World Journal of Pharmacy and Pharmaceutical Sciences 5(7): 16111621.

32. Tarinc D, Dogan Topal B, Golcu A, Ozkan SA (2014) Electrochemical investigation and determination of ceftazidime in pharmaceutical dosage forms and human urine. Journal of analytical chemistry 69(9): 899-908.

33. Nikolić K, Aleksić MM, Kapetanović V, Agbaba D (2015) Voltammetric and theoretical studies of the electrochemical behavior of cephalosporins at a mercury electrode. J Serb Chem Soc 80(8): 10351049.]

34. Wu AT, Massey IJ, Kushinsky S (1984) A high-performance liquid chromatographic method for the simultaneous determination of nicardipine and its pyridine metabolite II in plasma. J Pharm Sci 73(10): 1444-1447.

35. AR Barnes (1995) Determination of Ceftazidime and Pyridine by HPLC: Application to a Viscous Eye Drop Formulation. Journal of Liquid Chromatography 18(15): 3117-3128.

36. ICH, Q2 (R1) Validation of Analytical Procedures: Text and Methodology. ICH Harmonized Tripartite Guideline. 
This work is licensed under Creative

Commons Attribution 4.0 License
Your next submission with Juniper Publishers will reach you the below assets

- Quality Editorial service

- Swift Peer Review

- Reprints availability

- E-prints Service

- Manuscript Podcast for convenient understanding

- Global attainment for your research

- Manuscript accessibility in different formats

( Pdf, E-pub, Full Text, Audio)

- Unceasing customer service

Track the below URL for one-step submission https://juniperpublishers.com/online-submission.php 